International Research Journal of Management, IT \& Social Sciences
Available online at https://sloap.org/journals/index.php/irjmis/
Vol. 8 No. 6, November 2021, pages: 516-523
ISSN: 2395-7492
https://doi.org/10.21744/irjmis.v8n6.1938

\title{
Community Income of Honey Bee Cultivation in Protected Forest
} Edge Area

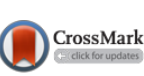

Gede Suarta ${ }^{a}$

I Gusti Ngurah Kayana ${ }^{b}$

I Gusti Agung Nyoman Dananjaya ${ }^{\mathrm{c}}$

Article history:

Submitted: 09 July 2021

Revised: 18 August 2021

Accepted: 27 September 2021

\section{Keywords:}

Apis;

bee;

cost;

honey;

income;

\begin{abstract}
This study aims to analyze the level of income, the minimum scale of the amount of honey beekeeping, and the minimum selling price for the honey produced so that farmers get profits. Determination of the location of the study using the purposive method with the consideration that Pempatan Village, Rendang District, Karangasem Regency is one of the honey centers. The population in this study amounted to 63 people who cultivate honey bees. Sampling in this study using purposive sampling method with the number of respondents as many as 30 people. The types of data needed in this study are primary data and secondary data. Primary data was obtained by conducting observations and interviews with respondents. The data analysis methods used in this study are (1) Revenue Analysis, (2) Revenue Cost Ratio, (3) Break Event point. Based on the research results, the community's income from honey bee cultivation is IDR. 3.369.300,-/month while the R/C ratio of honey bee cultivation in Pempatan Village is 2.1 , which means it is feasible to cultivate. If it is seen from the BEP Production from beekeeping is 7.08 liters, BEP Prices from honey bee cultivation are IDR. 154,516,-/liter and BEP Revenue from beekeeping is IDR. 2,337,145.
\end{abstract}

International research journal of management, IT and social sciences (C) 2021. This is an open access article under the CC BY-NC-ND license (https://creativecommons.org/licenses/by-nc-nd/4.0/).

\section{Corresponding author:}

Gede Suarta,

Animal Science Study Program, Faculty of Animal Husbandry, Udayana University, Denpasar, Indonesia.

Email address: gedesuarta8@gmail.com

\footnotetext{
animal Science Study Program, Faculty of Animal Husbandry, Udayana University, Denpasar, Indonesia

Animal Science Study Program, Faculty of Animal Husbandry, Udayana University, Denpasar, Indonesia Agribusiness Study Program, Faculty of Agriculture and Business, Dwijendra University, Denpasar, Indonesia 


\section{Introduction}

Indonesia is a country with a tropical climate and has enormous potential in beekeeping to produce honey quality. Indonesia is also known as a country that has very high biodiversity, both in the form of flora and fauna. Indonesia has a very large forest area with a total forest area of 94.1 million hectares, with abundant forest products. The wealth of forest resources has a high economic value that can support the welfare of the community (Durant, 2019; Geeraert et al., 2020). Non-timber forest products that are generally managed and utilized by the community are resins, essential oils, and honey. Honey is a non-timber forest product that has a high economic price.

The types of bees native to Indonesia include forest bees (Apis dorsata), local bees (Apis cerana), dwarf bees (Apis florea), small bees (Apis andreniformis), Borneo red bees (Apis koschevnikovi), mountain bees (Apis nuluensis), the local Sulawesi bee (Apis nigrocincta), and the stingless bee (Trigona Sp.) (Eva, 2016). Apis dorsata is commonly called the forest bee or wild bee. People often call it by the name of wasp gung (Javanese). This bee is difficult to raise because of its fierce nature and its sting is also quite dangerous for humans. This type of bee is widely found in the wilderness that is rarely traveled by humans. This type of bee is also called the giant bee because the house is very large and the inhabitants are millions of individuals. The diameter of the Apis dorsata beehive is approximately 1.5-2 meters. The production of honey at each harvest is around 50-60 kilograms. The shape of the nest of this type of bee is not like a bee's nest in general in the form of a comb, but the shape becomes a single unit (Sarwono, 2001). Worker bees prefer to seek nectar, pollen, and water closest to the hive, about 1-2 km (Hamzah, 2011).

Honey bees are one of the rural industrial businesses that can play a role in meeting the economic needs of the family so that they can support the community's economy. Honey is a food ingredient in the form of a thick liquid that has a naturally sweet taste produced by bees made from flower nectar. Honey is rich in nutrients and has many benefits for human health. Forest honey production has begun to be managed properly because the potential for forest honey is quite large. So that it can improve the economy of the community around the forest. Honey bees have long been cultivated by the community on the edge of a protected forest in Pempatan Village, Rendang District, Regency, both for personal consumption and as a product that can improve the community's economy. Honey is a non-timber forest product that is currently very potential to be developed because it has two main functions, namely: increasing the preservation of protected forests and also improving the community's economy. To improve the economy in the community, a community organization in the form of a farmer group is needed. The development of an organization in society is influenced by management in the organization. Organizations play a role in determining strategies in managing their organizations (Dananjaya et al, 2020).

Based on the above background, it is necessary to research the analysis of community income from honey bee cultivation in the edge of the protected forest area of Pempatan Village, Rendang District, Karangasem Regency. The results of this study are expected to provide information about the level of income of honey bee cultivation, the minimum scale of honey bee maintenance, and the minimum selling price for the honey produced so that farmers can benefit (Wiwekowati et al., 2017; Sihombing, 1997).

\section{Materials and Methods}

This research was conducted in Pempatan Village, Rendang District, Karangasem Regency. The selection of this location was determined by purposive sampling, namely the technique of determining location samples intentionally or with certain considerations. The consideration is that Pempatan Village, Rendang District, Karangasem Regency is one of the honey centers (Ramos et al., 2018; Sande et al., 2009). The population in this study amounted to 63 people who cultivate honey bees. Sampling in this study using purposive sampling method with the number of respondents as many as 30 people. The types of data needed in this study are primary data and secondary data. Primary data was obtained by conducting observations and interviews with respondents. Interviews were conducted in a structured manner with the help of a questionnaire. Secondary data was obtained by searching the literature related to the research. The data obtained will be analyzed qualitatively and quantitatively. Qualitative analysis was conducted to analyze the management conditions of honey bee cultivation. Quantitative analysis is used to analyze people's income from honey bee cultivation. The data collected was then tabulated and then analyzed to answer the research objectives. The data analysis methods used in this study are (1) Revenue Analysis, (2) Revenue Cost Ratio (R/C ratio), (3) Break Event point (BEP) (Utzeri et al., 2018; Requier et al., 2019).

Suarta, G., Kayana, I. G. N., \& Dananjaya, I. G. A. N. (2021). Community income of honey bee cultivation in protected forest edge area. International Research Journal of Management, IT and Social Sciences, 8(6), 516-523. 


\section{Results and Discussions}

\section{Research location overview}

Pempatan Village is one of 6 (six) villages in Rendang District with an area of 5377,887 Ha, most of which is plantation land, which is $690 \mathrm{Ha}$, while the rest is designated as yardland, moor, and others. The village of Pempatan is located at an altitude of 600-1100 m. Above sea level with a slope of 3-45o towards the north. While the population of Pempatan Village is 11221 people (3194 families), with details of 5748 men, where the population density is approximately 174/km2 (Profile of Pempatan Village, 2020). The boundaries of the Pempatan Village area.

- Northside: Bangli Regency

- Westside: Bangli Regency

- Southside: Menanga Village

- Eastside: Besakih Village

Pempatan Village has a sub-tropical climate with an average annual rainfall of 2000-2500 mm, namely the rainy season from October to April and the dry season from April to October. Meanwhile, the minimum air temperature is 27oC and the maximum is $360 \mathrm{C}$. The climate of Pempatan Village, like other villages in the territory of Indonesia, has a dry and rainy climate, this is related to the cropping pattern in the Pempatan Village (Pempatan Village Profile, 2020).

\section{Characteristics of respondents}

This study involved 30 community respondents in the Protected Forest Edge Area, Pempatan Village, Karangasem Regency. The identity of the respondents who took part in this research section includes the age, education level, and occupation of the respondent which will be described as follows.

Age

The characteristics of the respondents in this study when viewed from the age, the description of the distribution can be seen in Table 1 below:

Table 1

Frequency distribution of respondents age

\begin{tabular}{llll}
\hline No. & Age $(\mathrm{TH})$ & Frequency & Percentage $(\%)$ \\
\hline 1 & $<17$ & 0 & 0,00 \\
2 & $17-64$ & 26 & 86,67 \\
3 & $>64$ & 4 & 13,33 \\
Total & & 30 & 100 \\
\hline
\end{tabular}

Source: Data processed from survey results

Based on the results of the study, most respondents were aged 17-64 years with a percentage of $86.67 \%$, while respondents aged $>64$ years with a percentage of $13.33 \%$. This shows that respondents are still in the category of productive age, namely, respondents still have the potential of their workforce and higher labor productivity in raising honey bees.

\section{Education}

Based on the results of the tabulation of data carried out according to the educational background of the respondents, the following picture is obtained: 
Table 2

Frequency distribution of respondent's education level

\begin{tabular}{llll}
\hline No. & Education & Frequency & Percentage $(\%)$ \\
\hline 1 & No education & 0 & 0 \\
2 & SD & 3 & 10,00 \\
3 & SMP & 8 & 26,67 \\
4 & SMA/SMK & 17 & 56,67 \\
5 & Bachelor & 2 & 6,67 \\
Total & & 30 & 100 \\
\hline
\end{tabular}

Source: Data processed from survey results

Based on the results of the tabulation of data carried out according to the educational background of the respondents, it can be seen that the education level of respondents in the elementary category was 3 people with a percentage of $10.00 \%$, the junior high school category was 8 people with a percentage of $26.67 \%$ and Bachelor's were 2 people with a percentage of $6,67 \%$ while the highest is SMA/SMK as many as 17 people or $56.67 \%$. According to Suarta \& Dananjaya (2021), the age group is still young, namely the age where the ability to communicate is good because there is still a great willingness to innovate to be able to improve performance. This shows that the education level of the respondents to cultivate honey bees is very high.

\section{Occupation}

Characteristics of respondents in this study when viewed from the job, then the description of the distribution can be seen as in Table 3 below.

Table 3

Distribution of respondent's jobs

\begin{tabular}{llll}
\hline No. & Occupation & Frequency & Percentage $(\%)$ \\
\hline 1 & No Occupation & 2 & 6,67 \\
2 & Farmers/Breeder & 18 & 60,00 \\
3 & Labor & 7 & 23,33 \\
4 & Private sector employee & 3 & 10,00 \\
Total & & 30 & 100 \\
\hline
\end{tabular}

Based on the results of the study stated that the respondent's work as laborers was 7 people with a percentage of $23.33 \%$, private employees were 3 people with a percentage of $10.00 \%, 2$ people did not work with a percentage of $6.67 \%$ while the highest respondent's occupation was as follows: 18 farmers and ranchers with a percentage of $60.00 \%$. This condition shows that most of the respondents are in the agricultural and livestock sectors so that they can be better able to cultivate honey bees properly (Matias et al., 2018; Geslin et al., 2017).

\section{Honey income analysis}

Income analysis is carried out to know the actual income earned by the business owner and to help improve the management of the business. Income analysis has been used including as a guide for investment and decision making, as a means of production, and as a measure of business management efficiency and can be used as a benchmark for the management of business leaders. In the revenue analysis process, the steps needed include identifying business costs and benefits, determining plans for the main components of income and whether these components can still be increased or not, compiling the flow of production costs and revenues, identifying sources of revenue, and how much the costs will be. spent to make a profit. According to Soekartawi (2010), in analyzing income, it is necessary to pay attention to production costs, revenues, and net income.

Suarta, G., Kayana, I. G. N., \& Dananjaya, I. G. A. N. (2021). Community income of honey bee cultivation in protected forest edge area. International Research Journal of Management, IT and Social Sciences, 8(6), 516-523. 


\section{Honey cultivation cost}

Costs are all expenditures of funds that are calculated for business purposes. According to Soekartawi (2010), business costs are the amount of money paid by producers to purchase goods and services to run a business to get maximum results. Based on the results of the research, the costs used to consist of fixed costs and variable costs. According to Ibrahim (2003), fixed costs are costs that are fixed in number and continue to be issued even though the product produced is large or small, so the amount of fixed costs does not depend on the size of the product obtained. Fixed costs consist of equipment depreciation costs while variable costs include production facilities such as bottles for honey, insect repellent, and labor. The cost of production facilities is the cost incurred by honey farmers in the production process and making it into a product (Ullah et al., 2021; Brodschneider et al., 2019). In more detail, the costs incurred for honey cultivation can be seen in Table 4 .

Table 4

Honeybee cultivation costs in the protected forest edge area of Pempatan Village, Rendang District, Karangasem Regency

\begin{tabular}{lllll}
\hline Item cost-return & Volume & Unit & Unit Price (IDR) & Value (IDR) \\
\hline Fixed cost (FC) & & & & \\
Shrinkage (5th) & 32 & Item & $300.000,-$ & $1.920 .000,-$ \\
$\quad$ - Honey Stup & 2 & Item & $25.000,-$ & $10.000,-$ \\
$\quad$ - Harvest Knife & 4 & Item & $22.000,-$ & $17.600,-$ \\
$\quad$ - Honey Filter & 6 & Item & $18.000,-$ & $21.600,-$ \\
$\quad$ - Bucket & & & & $1.969 .200,-$ \\
\hline Total Fixed Cost (TFC) & & & & \\
\hline Variable Cost (vC) & 32 & Item & $2.500,-$ & $80.000,-$ \\
$\quad$ - Bottle 600 ml & 1 & Bottle & $37.500,-$ & $37.500,-$ \\
$\quad$ - Insect repellent & & & & \\
$\quad$ Labor costs & 8 & HOK & $80.000,-$ & $640.000,-$ \\
$\quad$ - Maintenance & 3 & HOK & $80.000,-$ & $240.000,-$ \\
$\quad$ - Harvest & & & $997.500,-$ \\
Total Variable Cost (TVC) & & & & $2.966 .700,-$ \\
Total Cost : TFC + TVC & &
\end{tabular}

Source: Data processed from survey results

Based on the results of the study in Table 4, the total fixed costs (TFC) of IDR. 1,969,200,- and variable costs (TVC) of IDR. 997,500,- are obtained. So the total cost (TC) of honey cultivation in the Protected Forest Edge Area of Pempatan Village is IDR. 2,966,700,-.

\section{Honey cultivation acceptance}

Revenue is the entire proceeds from the sale of products in a business within a certain period and is expressed in the form of rupiah. Revenue is the result of multiplying the total production amount and the unit price of a product. This statement is supported by Soekartawi (2010), that revenue is the total value of the product that is carried out which is the result of multiplying the physical amount of output with the price or value of money received from the sale of business products. certain. Based on the results of the study, the average production of honey farmers in Pempatan Village, Rendang District, Karangasem Regency was 19.2 liters/month, where the prevailing price at the time of the study was IDR. 330,000,-/liter. So the revenue from honey cultivation can be calculated as follows:

$\mathrm{TR} \quad=\mathrm{Q} \cdot \mathrm{P}$

$=19,2$ liter $\mathrm{x}$ IDR 330.000

$=$ IDR 6.336.000,-

Based on the above calculation, the revenue from honey cultivation in the Protected Forest Edge Area of Pempatan Village is R IDR. 6,336,000, -/month. 


\section{Honey cultivation income}

Income is the difference between revenue and costs of honey cultivation. To find out the income of honey cultivation is calculated through receipts minus the total costs incurred for honey cultivation (Button \& Elle, 2014; Wilson, 1990). The average amount of honey cultivation revenue is IDR. 6,336,000,-/month while the average cost of honey cultivation is IDR. 2,966,700,-. So based on the calculation, the average income from honey cultivation is:

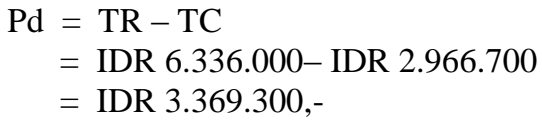

Based on the above calculation, the income of honey cultivation in the Protected Forest Edge Area of Pempatan Village is IDR. 3.369.300,-/month.

\section{Revenue cost ratio $(R / C$ ratio)}

Economically, a business is said to be profitable or unprofitable. It can be analyzed using a comparison between total revenue and total cost, called the Revenue Cost Ratio ( $\mathrm{R} / \mathrm{C}$ ratio), which is formulated as follows (Hastuti \& Rahim, 2007). Based on the results of the study, it can also be explained that the $\mathrm{R} / \mathrm{C}$ ratio or the comparison between revenue (revenue) and cost (costs), namely:

$$
\begin{aligned}
\mathrm{R} / \mathrm{C} \text { ratio } & =\frac{6.336 .000}{2.966 .700} \\
& =2,1
\end{aligned}
$$

The 2,1 means that each additional unit cost of the honey cultivation production process will provide additional revenue of 2,1 units of rupiah. This means that honey cultivation is feasible to cultivate.

\section{Break even point (BEP)}

In this study, the calculation of break-even point (BEP) can be calculated using the formula as follows:

1) The BEP formula used to calculate the liters of honey that must be produced to the break-even point in this study is as follows:

$$
\begin{aligned}
\mathrm{BEP} \text { Production } & =\frac{1.969 .200}{330.000-51.953} \\
& =7,08 \text { liter }
\end{aligned}
$$

This shows that 7.08 liters of honey are produced to reach BEP.

2) The BEP formula to calculate the price per liter for BEP to occur in this study is as follows:

$$
\begin{aligned}
\mathrm{BEP}_{\text {Price }} & =\frac{2.966 .700}{19,2} \\
& =\operatorname{IDR} 154.516,- \text { /liter }
\end{aligned}
$$

This shows that for IDR. 154,516,-/liter honey produced is to reach BEP.

3) The BEP formula to calculate how much sales revenue is received for BEP to occur in this study is as follows:

$$
\begin{aligned}
\mathrm{BEP}_{\text {Return }} & =\frac{1.969 .200}{1-\frac{51.953}{330.000}} \\
& =\text { IDR 2.337.145,- }
\end{aligned}
$$

Suarta, G., Kayana, I. G. N., \& Dananjaya, I. G. A. N. (2021). Community income of honey bee cultivation in protected forest edge area. International Research Journal of Management, IT and Social Sciences, 8(6), 516-523. 
This shows that with an income of IDR 2,337,145, - which is received to achieve BEP.

\section{Conclusion}

Based on the results and discussion above, it can be concluded that:

- The community's income from honey bee cultivation in the Protected Forest Edge Area of Pempatan Village is IDR. 3.369.300,-/month.

- The large R/C ratio of honey bee cultivation in the Protected Forest Edge Area of Pempatan Village is 2.1, which means it is feasible to cultivate.

- BEP Production from honey bee cultivation in the Protected Forest Edge Area of Pempatan Village is 7.08 liters.

- BEP The price of honey bee cultivation in the Protected Forest Edge Area of Pempatan Village is IDR. 154,516,/liter.

- BEP Revenue from honey bee cultivation in the Protected Forest Edge Area of Pempatan Village is IDR. $2,337,145,-$.

\section{Suggestion}

Based on the results of the analysis and discussion that has been carried out in this study, some suggestions can be given as follows:

- The role of the Karangasem Regency Government is very much needed to facilitate the community in assisting the procurement of honey-stup and honey marketing.

- Honey farmers are strived to continue to develop the honey farm business because it has a very large business opportunity.

- The community is expected to continue to innovate in managing the honey farm business so that the Protected Forest Edge Area of Pempatan Village, becomes a honey village agro-tourism place.

Conflict of interest statement

The authors declared that's they have no competing interests.

Statement of authorship

The authors have a responsibility for the conception and design of the study. The authors have approved the final article.

Acknowledgments

We are grateful to two anonymous reviewers for their valuable comments on the earlier version of this paper. 


\section{References}

Brodschneider, R., Brus, J., \& Danihlík, J. (2019). Comparison of apiculture and winter mortality of honey bee colonies (Apis mellifera) in Austria and Czechia. Agriculture, Ecosystems \& Environment, $274,24-32$. https://doi.org/10.1016/j.agee.2019.01.002

Button, L., \& Elle, E. (2014). Wild bumble bees reduce pollination deficits in a crop mostly visited by managed honey bees. Agriculture, Ecosystems \& Environment, 197, 255-263. https://doi.org/10.1016/j.agee.2014.08.004

Dananjaya, I. G. A. N., Suparyana, P. K., Setiawan, I. M. D., \& Yuniti, I. G. A. D. (2020). Strategi Pengembangan Kegiatan Ekonomi Kreatif PKK di Kota Tabanan terhadap Peningkatan Pendapatan Anggota. JIA (Jurnal Ilmiah Agribisnis): Jurnal Agribisnis dan Ilmu Sosial Ekonomi Pertanian, 5(6), 207-221.

Durant, J. L. (2019). Where have all the flowers gone? Honey bee declines and exclusions from floral resources. Journal of Rural Studies, 65, 161-171. https://doi.org/10.1016/j.jrurstud.2018.10.007

Eva, E. (2016). Strategi Pengembangan Budidaya Lebah Madu Di Desa Buana Sakti Kecamatan Batang Hari Kabupaten Lampung Timur (Doctoral dissertation, STIPER DHARMA WACANA METRO).

Geeraert, L., Aerts, R., Berecha, G., Daba, G., De Fruyt, N., D’hollander, J., ... \& Honnay, O. (2020). Effects of landscape composition on bee communities and coffee pollination in Coffea arabica production forests in southwestern Ethiopia. Agriculture, Ecosystems \& Environment, $288, \quad 106706$. https://doi.org/10.1016/j.agee.2019.106706

Geslin, B., Aizen, M. A., Garcia, N., Pereira, A. J., Vaissière, B. E., \& Garibaldi, L. A. (2017). The impact of honey bee colony quality on crop yield and farmers' profit in apples and pears. Agriculture, ecosystems \& environment, 248, 153-161. https://doi.org/10.1016/j.agee.2017.07.035

Hamzah, D. (2011). Produksi Lebah Madu (Apis cerana) yang Dipelihara Pada Sarang Tradisional dan Moderen di Desa Kuapan Kecamatan Tambang Kabupaten Kampar (Doctoral dissertation, Universitas Islam Negeri Sultan Sarif Kasim Riau).

Hastuti, D. R., \& Rahim, A. (2007). Ekonomika Pertanian (pengantar, Teori, dan kasus). Jakarta: Penebar Swadaya, 11(1), 75-88.

Ibrahim, Y. (2003). Studi kelayakan bisnis.

Matias, D. M. S., Tambo, J. A., Stellmacher, T., Borgemeister, C., \& von Wehrden, H. (2018). Commercializing traditional non-timber forest products: An integrated value chain analysis of honey from giant honey bees in Palawan, Philippines. Forest Policy and Economics, 97, 223-231. https://doi.org/10.1016/j.forpol.2018.10.009

Ramos, J. L. M., Pérez, A. V., Gámez, M. R., \& Zambrano, R. V. H. (2018). Renewable energy sources on the change of energy matrix in Manabí province. International research journal of engineering, IT \& scientific research, 4(4), 17-29.

Requier, F., Garnery, L., Kohl, P. L., Njovu, H. K., Pirk, C. W., Crewe, R. M., \& Steffan-Dewenter, I. (2019). The conservation of native honey bees is crucial. Trends in ecology \& evolution, 34(9), 789-798. https://doi.org/10.1016/j.tree.2019.04.008

Sande, S. O., Crewe, R. M., Raina, S. K., Nicolson, S. W., \& Gordon, I. (2009). Proximity to a forest leads to higher honey yield: Another reason to conserve. Biological conservation, 142(11), $2703-2709$. https://doi.org/10.1016/j.biocon.2009.06.023

Sarwono, B. (2001). Lebah madu. Jakarta Agromedia pustaka.

Sihombing, D. T. H. (1997). Ilmu ternak lebah madu. Gadjah Mada University Press.

Soekartawi. (2010). Agribisnis, Teori dan Aplikasinya. PT Raja Grafindo Persada, Jakarta.

Suarta, G., \& Dananjaya, I. G. A. N. (2021). Community Motivation in Raising Kele Honey (Trigona Sp) in Gegelang Village, Manggis District, Karangasem Regency.

Ullah, A., Shahzad, M. F., Iqbal, J., \& Baloch, M. S. (2021). Nutritional effects of supplementary diets on brood development, biological activities and honey production of Apis mellifera L. Saudi Journal of Biological Sciences. https://doi.org/10.1016/j.sjbs.2021.07.067

Utzeri, V. J., Ribani, A., \& Fontanesi, L. (2018). Authentication of honey based on a DNA method to differentiate Apis mellifera subspecies: Application to Sicilian honey bee (A. m. siciliana) and Iberian honey bee (A. m. iberiensis) honeys. Food Control, 91, 294-301. https://doi.org/10.1016/j.foodcont.2018.04.010

Wilson, E. B. (1990). An introduction to scientific research. Courier Corporation.

Wiwekowati, W., Astawa, P., Jawi, I. M., \& Sabir, A. (2017). Antioxidant activity of Apis mellifera sp. Propolis extract from Java (Indonesia). International Research Journal of Engineering, IT and Scientific Research, 3(5), 19-24.

Suarta, G., Kayana, I. G. N., \& Dananjaya, I. G. A. N. (2021). Community income of honey bee cultivation in protected forest edge area. International Research Journal of Management, IT and Social Sciences, 8(6), 516-523. 